\title{
Impact of DHA on Metabolic Diseases from Womb to Tomb
}

\author{
Ilse A. C. Arnoldussen ${ }^{\dagger}$ and Amanda J. Kiliaan ${ }^{\dagger, *}$ \\ Department of Anatomy, Donders Institute for Brain, Cognition \& Behaviour, \\ Radboud University Medical Center, Geert Grooteplein Noord 21, 6525 EZ Nijmegen, \\ The Netherlands; E-Mail: Ilse.Arnoldussen@radboudumc.nl
}

$\dagger$ These authors contributed equally to this work.

* Author to whom correspondence should be addressed; E-Mail: Amanda.Kiliaan@Radboudumc.nl; Tel.: +31-24-361-4378; Fax: +31-24-361-3789.

External Editor: Constantina Nasopoulou

Received: 9 October 2014; in revised form: 25 November 2014 / Accepted: 11 December 2014 / Published: 18 December 2014

\begin{abstract}
Long chain polyunsaturated fatty acids (LC-PUFAs) are important mediators in improving and maintaining human health over the total lifespan. One topic we especially focus on in this review is omega-3 LC-PUFA docosahexaenoic acid (DHA). Adequate DHA levels are essential during neurodevelopment and, in addition, beneficial in cognitive processes throughout life. We review the impact of DHA on societal relevant metabolic diseases such as cardiovascular diseases, obesity, and diabetes mellitus type 2 (T2DM). All of these are risk factors for cognitive decline and dementia in later life. DHA supplementation is associated with a reduced incidence of both stroke and atherosclerosis, lower bodyweight and decreased T2DM prevalence. These findings are discussed in the light of different stages in the human life cycle: childhood, adolescence, adulthood and in later life. From this review, it can be concluded that DHA supplementation is able to inhibit pathologies like obesity and cardiovascular disease. DHA could be a dietary protector against these metabolic diseases during a person's entire lifespan. However, supplementation of DHA in combination with other dietary factors is also effective. The efficacy of DHA depends on its dose as well as on the duration of supplementation, sex, and age.
\end{abstract}

Keywords: docosahexaenoic acid; humans; metabolic diseases; cardiovascular disease; obesity; diabetes mellitus type II 


\section{Introduction}

Since the early 1970s, scientists have studied the role of omega-3 LC-PUFA docosahexaenoic acid (DHA) in human health. Currently, it has been shown that DHA may be beneficial in several human pathologies like cardiovascular diseases, obesity, and diabetes mellitus type 2 (T2DM); DHA is associated with a reduced incidence of stroke, atherosclerosis, lower bodyweight and decreased T2DM prevalence [1-7]. Nevertheless, research findings are ambiguous and argue over the supplemented dose and duration of the supplementation in relation to sex and age differences. In this review, the impact of long chain polyunsaturated fatty acids (LC-PUFAs) on current societally highly relevant metabolic diseases in humans will be discussed, and, in particular, the role of DHA in connection with diabetes type II (T2DM), obesity, and cardiovascular disease (CVD). The following categories are described in this review: childhood, adolescence, adulthood, as well as mature and late adulthood, to indicate the effect of DHA on metabolic diseases in critical stages of life.

We searched the PubMed database for original and review articles in English, published from 1993 to August 2014. The main search topics concerned DHA, the influence of DHA on disorders such as T2DM, obesity and CVD. The search strategy was based on the following search terms: DHA, LCPUFA, obesity, T2DM, CVD, childhood, adolescence, adulthood, and the elderly. Moreover, we filtered our total list of relevant papers by hand, in order to identify new, potentially relevant papers. We selected the studies based on titles and abstracts, a selection of these two components was not sufficient, we evaluated the whole publication instead.

\section{Docosahexaenoic Acid (DHA)}

Humans need to obtain adequate levels of essential fatty acids from dietary sources. These lipids are important constituents of phospholipids, which are the building blocks of all membranes. An important constituent is the essential fatty acid alpha-linolenic acid (ALA), which can be found, for example, in soy beans, flaxseed, linseed and walnut oils [8]. Based on its molecular structure, three double cis-bonds and an 18-carbon chain, ALA is classified as a long chain polyunsaturated fatty acid (LC-PUFA) (Figure 1). ALA can be converted into two other LC-PUFAs: docosahexaenoic acid (DHA) and eicosapentaenoic acid. The first step in this process is to convert ALA into an active metabolic product, i.e., eicosapentaenoic acid (EPA) (Figure 1) $[9,10]$. This is done through a double bond creation at the 6 th and 5 th position ( $\Delta 6$ - and $\Delta 5$-desaturase), and an elongase at the double bond at the 6 th position ( $\Delta 6$-elongase). Subsequently, EPA can be metabolized into DHA via $\Delta 5$-elongation and $\Delta 4$-desaturation (Figure 1) $[9,10]$. The described process is limited, and it only occurs in the liver, the cerebrovascular lumen, and astroglial cells $[9,11,12]$. DHA can be converted into potent novel molecules with anti-inflammatory and organ-protective properties [13-17] such as the specialized pro-resolving lipid mediators (SPMs), including D- and E-series resolvins, neuroprotectins, and maresins (Figure 1) [15-19] via specialized chemical mediators.

DHA can also be obtained directly from dietary sources such as deep-sea fish, whereby white fish such as cod and haddock contain a lower concentration of DHA than oily fish like Atlantic salmon, blue mackerel and sardines [8,20,21]. In cold-water deep sea fish, DHA is accumulated through consumption of marine microalgae which are able to synthesize DHA [22]. Cold-water deep-sea fish that live in oceanic seas with high water pressure and low temperatures need adequate levels of long chain poly-unsaturated 
fatty acids like DHA to maintain functional membrane fluidity. Neuronal membranes containing high concentrations of saturated fatty acids would become rigid and lose functionality in these cold oceanic seas [23].

Figure 1. Classification of long chain polyunsaturated fatty acids (LC-PUFAs). PUFAs are subdivided into two subclasses: omega-6 and omega-3 PUFAs. Within the omega-6 PUFAs class precursor fatty acid, (i.e.,) linoleic acid (LA), is converted into arachidonicacid (AA) via $\Delta 6$-desaturase, $\Delta 6$-elongase and $\Delta 5$-desaturase. Subsequently, AA can be metabolized into docosapentaenoic acid (DPA) via $\Delta 5$-elongase. In the omega-3 fatty acid class, the precursor fatty acid, i.e., $\alpha$-linoleic acid (ALA), is converted into eicosapentaenoic acid (EPA) via $\Delta 6$-desaturase, $\Delta 6$-elongase and $\Delta 5$-desaturase, which can subsequently be converted into docosahexaenoic acid (DHA) via $\Delta 5$-elongase and $\Delta 4$-desaturase. DHA is the precursor of several bioactive products, because it can be converted via enzymatic and non-enzymatic oxidation. DHA can be metabolized into e.g., resolvins E1 \& E2 and D1-D5, maresin-1 and neuroprotectin D1 by means of enzymatic oxidation. These eicosanoids can enter the nucleus where they downregulate gene expression, promote inflammation or enter the bloodstream. This is where they reduce platelet aggregation and accumulation of fatty acids in the arteries. In non-enzymatic oxidation, DHA can be oxidized by radical oxygen species into lipid peroxides such as neuroprostanes, isoprostanes, aldehydes and 4-hydroxyhexenal. These peroxides can activate transcription factors such as peroxisome proliferator-activated receptors (PPARs) and nuclear factor-like 2 (Nrf2), which upregulate gene expression in the nucleus. $(\Delta 6 / \Delta 5 / \Delta 4$ : at the double bond at the 6 th/5th/4th position).

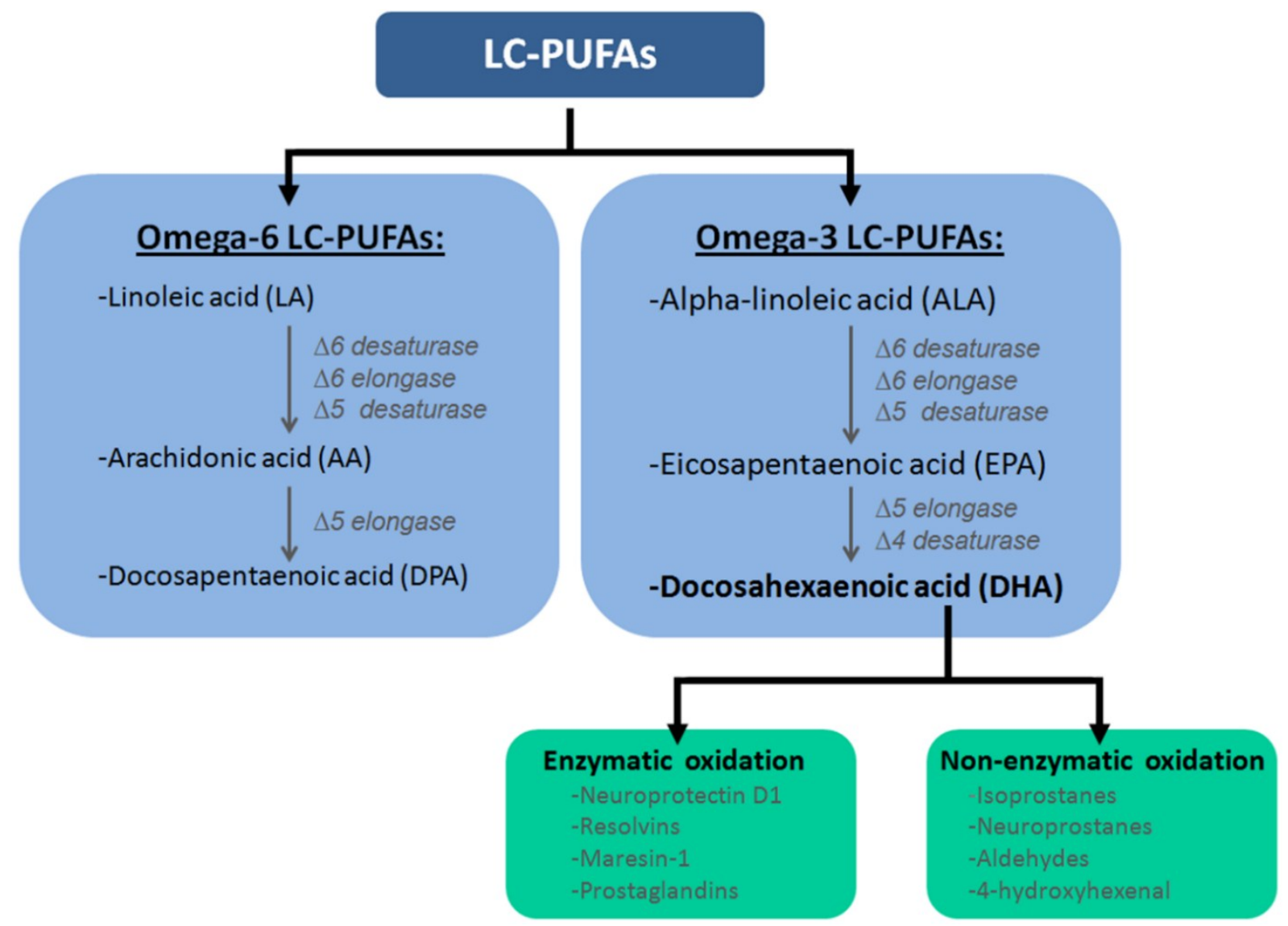


DHA is an essential component in phospholipids because it maintains membrane fluidity. Membrane fluidity can be defined as the optimum transition point between gel and liquid crystal where the neuronal lipid bilayer can exist. This condition is of physiological importance for signal transmission. It can be strongly influenced by fatty acid composition and should therefore be maintained optimal [24]. Dietary intake of specific fatty acids can modify the lipid composition of neurons up to a certain degree [24]. Prolonged intake of DHA, for example, will modestly increase brain DHA content and decrease brain omega-6 PUFAs content simultaneously, particularly docosapentaenoic acid (DPA) [25]. High concentrations of DHA within the lipid bilayer provide neuronal membranes with the flexibility/fluidity that is required in order to function properly during axonal and synaptic growth, and improve functioning of ion-channels and receptors through better transmission [14,24,26-28]. This is contrary to the fact that complete long term dietary deprivation of omega-3 PUFAs depletes the brain of DHA, but will specifically increase the brain DPA content of the omega-6 PUFAs family [24]. Thus, the concentration of unsaturated fatty acids will be more or less maintained, but the functionality of the membranes can differ drastically because of changes in omega- 3 and omega- 6 ratios. In addition, membrane fluidity will change, possibly causing impairment of proper membrane function and signal transmission [24].

It has been demonstrated that in mammals, DHA, in free form, rapidly crosses the blood brain barrier (BBB), similar to freely diffusible lipophilic drugs [29]. The first transport mechanisms of omega-3 PUFAs into the cell is described as a rapid diffusion flip-flop across cell membranes [30]. Others suggest a protein mediated uptake via fatty acid transport proteins (FATPs), fatty acid binding proteins (FABPs), fatty acid translocases (FATs), long chain fatty acyl-CoA synthetases (ACSL) or long chain fatty acyl-CoA binding proteins (ACBPs) [31-38]. Flip-Flop diffusion and protein-mediated transmembrane transfer seem to co-exist as two separate ways of fatty acid transport into the cell, in which the nature of the membrane, type and functional state of the cell, availability and type of fatty acids and differences in hormonal environment could be important $[39,40]$.

\section{Metabolic Diseases}

There is an emerging epidemic of obesity in people among all ages in Western societies, and it is now burgeoning in non-Western societies. Each year, obesity or obesity-related health conditions lead to the death of 2.8 million adults around the world [41]. Even though it has an undefined aetiology, it is generally caused by an imbalance of energy intake versus energy output. This results in excessive adipose tissue accumulation that may eventually have an adverse effect on human health. The epidemic of overweight and obesity has caused a dramatic increase in the number of individuals who are suffering from T2DM and premature cardiovascular disease (pCVD) [42]. In the U.S., for example, two-thirds (167 million) of adults are diagnosed as being overweight or obese, and another 26 million have T2DM [43]. It has been estimated that approximately $80 \%$ of all new T2DM cases are due to obesity [44]. Currently, T2DM is the most common metabolic disorder, and it has reached epidemic proportions in many countries [45]. Insulin resistance and inflammation have played a central role in the pathogenesis of T2DM and both have developed long before the onset of the disease [45]. The two to fourfold increase in cardiovascular morbidity as well as mortality in diabetic individuals is a major concern [45]. T2DM increases the risk of both heart disease and stroke as $50 \%$ of people with diabetes die from CVD [46]. Insulin 
signaling plays a critical role in normal vascular function via endothelial cell nitric oxide production, modulation of calcium handling and sensitivity in vascular smooth muscle cells [43].

Patients with T2DM and/or obesity have a significantly increased risk of heart attack and stroke when compared to people who have a normal insulin sensitivity and a normal weight [43]. Thus we can conclude that metabolic diseases like CVD, T2DM and obesity, are highly intercorrelated and reinforce each other. Studies have shown that DNA, as a dietary component, has beneficial effects on these three metabolic diseases [2,3,6,47-50]. DHA supplementation seems to affect symptoms of metabolic diseases by reducing plasma triglyceride levels, increasing glucose and insulin sensitivity, as well as reducing atherosclerosis. DHA could affect these characteristics through mediating processes such as reducing adipocyte differentiation, decreasing adipocyte apoptosis, improving lipolysis as well as insulin metabolism, decreasing production of proinflammatory cytokines, improving endothelial function and activating large-conductance calcium and voltage-activated potassium (BK) channels [51-55].

\subsection{Processes Mediated by DHA}

\subsubsection{Inflammation}

It has been shown that DHA is capable of reducing several inflammatory mechanisms which can be of importance in the pathology of CVD, T2DM and obesity. For instance, in Pickup et al. [56] it was hypothesized that the innate immune system is involved in the pathogenesis of T2DM. Tumor necrosis factor alpha (TNF- $\alpha$ ), as well as interleukin-1 \& 6 (IL-1 \& IL-6) are known to play a major role in the pathophysiology of insulin resistance in T2DM [57]. Moreover, endothelial dysfunction in cardiovascular disease involves many inflammatory processes, and, for instance cytokine overproduction is associated with endothelial dysfunction and atherosclerosis [51,52]. For example, TNF- $\alpha$ can accelerate experimental atherosclerosis processes in vivo in human and rat veins, mainly through induction of adhesion molecule expression in endothelial and vascular smooth muscle cells, resulting in altered endothelium-dependent vasodilation and promotion of endothelial cell apoptosis [51,52,58,59]. In obesity, low state chronic adipose inflammation is an early characteristic and DHA is capable of decreasing this low state chronic adipose inflammation [60]. For example, DHA is able to downregulate tumor necrosis factor- $\alpha$ (TNF- $\alpha$ ), interleukin-6 (IL-6) and monocyte chemotactic protein-1 (MCP-1) secretion in human adipose tissue and adipocytes cultures [61]. Resolvin D1, an anti-inflammatory SPM converted from DHA (Figure 1), increases both the number of macrophages containing ingested particles and the number of phagocytosed particles in adipose tissue, and also reduces macrophage reactive oxygen species production [62]. In conclusion, these findings illustrate novel mechanisms through which resolvin D1 and its precursor DHA may confer anti-inflammatory actions [62].

\subsubsection{Insulin Metabolism}

DHA may be able to partly restore insulin resistance, which is associated with an increased risk of developing T2DM [63-67]. In an obesity mouse model (ob/ob), dietary intake of omega-3 PUFAs induced an increase in adiponectin, a regulator to maintain the energy balance [53]. Bioactive SPMs, resolvins E1 and NPD1 (Figure 1), mimicked the insulin-sensitizing effects and induced adiponectin expression to a similar extent to that of rosiglitazone, a member of the thiazolidinedione family of antidiabetic drugs [53]. 
Together, these findings reveal effects of DHA and its bioactive SPMs in preventing obesity-induced insulin resistance via mimicking insulin sensitizing and expression of adiponectin.

\subsubsection{Adipocytes}

It has been demonstrated that DHA is involved in reducing symptoms of obesity via inhibiting adipocyte differentiation [60,67-73]. The direct effect of DHA on cell growth, differentiation, apoptosis, and lipolysis in adipocyte cell cultures was investigated [74]. Proliferation of preconfluent pre-adipocytes was not affected by the DHA treatment, but by DHA inhibited differentiation-associated mitotic clonal expansion [74]. DHA decreased mean droplet size and percent lipid area in adipocytes in a dose-dependent manner and, moreover, postconfluent pre-adipocytes demonstrated apoptosis after DHA treatment [74]. Additionally, DHA increased basal lipolysis in fully differentiated adipocytes [74]. These findings indicate that DHA may exert its obesity lowering effect by inhibiting differentiation of pre-adipocytes, inducing apoptosis in postconfluent pre-adipocytes and promoting lipolysis in adipocyte cell culture [74].

\subsubsection{Cardiovascular Health}

It is well-known that omega-3 LC-PUFAs are able to improve vascular function; these effects were first described in Greenland Inuits [75]. Research revealed that omega-3 LC-PUFAs prevent myocardial infarction and arrhythmia, decrease systolic and diastolic blood pressure and improve vascular function [76-80]. Individuals receiving omega-3 LC-PUFA supplementation, for example, had a decreased risk ratio in cardiac events like atrial fibrillation, nonfatal myocardial infarction and stroke [76,78-80]. Omega-3 LC-PUFAs have been shown to decrease systolic and diastolic blood pressure and development of hypertension [77]. In Thies et al. it was reported that consumption of omega-3 LC-PUFAs contributed to the stability of atherosclerotic plaques [81]. In Baumann et al. it was shown that the transcription of pro-inflammatory molecules was decreased after taking an omega-3 LC-PUFA supplementation for four weeks, followed by an improved vascular reactivity and endothelial function [80,82]. In addition, omega-3 LC-PUFAs can improve vascular function via endothelium relaxation [83]. It has been shown in in vivo studies that endothelium relaxation was higher in rodents and humans treated with omega-3 PUFAs [58,59,84]. Moreover, it was reported that DHA rapidly and reversibly activates BK-channels [54]. In vascular smooth muscle cells, BK-channels provide a critical vasodilatory influence [54]. BK channels are thus possible receptors for DHA and by activating these BK channels, blood pressure may be lowered [54].

\subsection{DHA \& Metabolic Diseases in Childhood}

Prevalence of childhood overweight and obesity has rapidly increased worldwide, and at the same time prevalence of T2DM and CVD has increased, even from a very early age [85]. To illustrate this, two-thirds of severely obese children aged 12 or younger develop cardiovascular risk factors [85]. In a study of Salvatore et al. [86] performed in the USA, $80 \%$ of the obese children had a low high-density lipoprotein (HDL) cholesterol level which is a risk factor for atherosclerosis [86]. In the Netherlands in $2009,13.3 \%$ of the boys and $14.9 \%$ of the girls were diagnosed with obesity, and $62 \%$ of these obese children aged 12 or younger developed hypertension [85]. It was shown that a daily supplementation of 
omega-3 LC PUFA improves vascular function and lowers the degree of inflammation in obese adolescents [47]. Interestingly, daily consumption of $300 \mathrm{mg}$ DHA and $42 \mathrm{mg}$ for a period of three weeks led to improvement of the anthropometric and lipid parameters in obese children aged 8-12 years [87]. Damsgaard et al. found that DHA plasma levels were positively associated with mean arterial pressure in boys. Moreover, girls had a higher body fat percentage, increased diastolic blood pressure and heart rate, elevated plasma triglyceride and insulin levels, and increased insulin resistance and glycosylated hemoglobin in comparison to boys [88]. Burrows et al. [2] and Decsi et al. [3] revealed that lower levels of DHA in plasma phospholipids are associated with insulin resistance, T2DM and obesity in children. Moreover, Juarez-Lopez et al. found that a LC-PUFA supplementation for a 12-week period reduced BMI and decreased the concentrations of glucose, insulin, triglyceride-levels in the plasma of obese children [89]. These findings indicate that an adequate level of DHA may be of importance in the prevention of these chronic diseases in later life $[2,3]$.

Thus, DHA levels in childhood are associated with reduced plasma insulin, glucose and triglyceride levels. These are all characteristics of obesity and T2DM, and, therefore, an adequate LC-PUFA level may be of great importance in preventing metabolic diseases later in life. Nonetheless, other LC-PUFAs such as EPA may contribute towards this prevention as well as factors such as sex and age differences.

\subsection{DHA \& Metabolic Diseases in Adolescence}

Obesity in children continues to evolve into adolescence, and thereby it contributes to the risk of health problems like insulin resistance, hypertension and even brain abnormalities [85,90,91]. Omega-3 PUFAs supplementation, including DHA, has beneficially affected female obesity in adolescence as it improved glucose tolerance by $39 \%$ and restored insulin concentration by $34 \%$ during an intravenous glucose tolerance test (IVGTT) [92]. In contrast, with regard to male obesity in adolescence, neither of these two parameters were influenced by omega-3 PUFAs supplementation [92]. In conclusion, omega-3 PUFAs supplementation seems to be beneficial in restoring insulin concentration and glucose tolerance in adolescent girls [92], which additionally indicates that sex differences can be differentially affected by omega-3 LC-PUFA supplementation (Table 1).

Risé et al. examined blood fatty acid levels particularly LC-PUFA levels in Italian neonates, children, adults and the elderly, and they found that LC-PUFA levels indicated significant differences due to age and sex [93]. In addition, Damsgaard et al. and Dangardt et al. found differences in DHA plasma levels, glucose tolerance, diastolic blood pressure, heart rate, plasma triglyceride and insulin levels, homeostasis model assesment-insulin resistance and glycosylated levels between sexes [88,92]. These findings emphasize that the differing need for LC-PUFAs like DHA depends on age and sex. Future research should therefore focus on these diverse needs of sex and age.

\subsection{DHA and Metabolic Diseases in Adults}

Prevalence of obesity, T2DM and CVD increases enormously in adults in the western world [41,94]. In the US in 2012, 167 million adults were obese or overweight, 36 million adults had CVD and 24 million adults suffered from T2DM [95]. Labonte et al. [96] suggested a minor impact of DHA on T2DM incidence in adults [97]. However, Stirban et al. [98] revealed that individuals with T2DM who received an omega-3 LCPUFA supplementation for a period of six weeks showed a postprandial decrease in macrovascular 
function (Table 1) [98]. These observations suggest that omega-3 LC PUFAs protect the macrovascular function in individuals with T2DM [98].Secondly, Virtanen and colleagues reported that men with higher serum level of LC-PUFAs had a 33\% lower multivariate-adjusted risk for T2DM [99]. (Table 1). Purified DHA supplementation reduced both collagen aggregation and collagen-stimulated thromboxane release in hypertensive diabetic individuals, making DHA an effective anti-thrombotic agent [100]. In hypertensive T2DM patients it was shown that a DHA and EPA supplementation during eight weeks can diminish platelet superoxide production, which suggests a therapeutic role for DHA as well as EPA in reducing vascular-derived oxidative stress associated with T2DM [101]. Supplementation with purified DHA reduces serum triglycerides and collagen aggregation, increases high-density lipoprotein 2 (HDL2) cholesterol, besides improving blood pressure [100,102-105]. In obese adults, higher plasma levels of total omega-3 PUFAs are associated with a healthier BMI, waist circumference and hip circumference [6]. DHA supplementation decreased plasma triglycerides and VLDL-triglycerides in noninsulin-dependent diabetes mellitus (NIDDM) hypertriglyceridemia patients and hypertriglyceridemic men [106,107]. Moreover, supplementation with conjugated linoleic acids (CLAs) plus omega-3 LC-PUFAs prevents increased abdominal fat mass and raises fat-free mass and adiponectin levels in obese adults, without deleteriously affecting insulin sensitivity, whereas in lean adults these parameters were unaffected [108]. More specifically, LC-PUFA supplementation decreased the gene expression of most analyzed inflammatory genes in subcutaneous adipose tissue, and increased production of anti-inflammatory eicosanoids in visceral adipose tissue and subcutaneous adipose tissue [109]. Furthermore, it has been shown that treatment with omega-3 PUFAs diminishes adipocyte differentiation, stimulates adipocyte apoptosis, improves lipid metabolism and systemic inflammation [5,62,84,98,108-110], through previously described processes such as anti-inflammatory, adipocyte apoptosis and differentiation.

A well-studied effect of LC-PUFAs, EPA and DHA is that intake of these fatty acids protects against cardiovascular disease because it decreases blood pressure and atherosclerosis formation [75,111-114]. These beneficial effects are due to the capacity to prevent arrhythmias, thus improving vasoactivity, decreasing blood pressure and inflammation and decreasing atherosclerosis [75,83,110-120]. The advantages of taking omega-3 LC-PUFA supplementation are that arrhythmias is prevented, vasoactivity is improved and blood pressure, inflammation and atherosclerosis are decreased [1,75,83,110-121]. Nevertheless, it was revealed that in healthy adults DHA supplementation did not improve the endothelial function [7].

Thus, omega-3 LC-PUFA supplementation may mainly affect obesity in adults by reducing adiposity and inflammation, and LC-PUFAs may improve vascular function by reducing the blood pressure, heartrate and coronary calcification. Nonetheless, research findings are ambiguous and therefore more research is needed, while taking dosing and duration of LC-PUFA or DHA supplementation into account. 
Table 1. DHA and metabolic diseases through lifetime.

\begin{tabular}{|c|c|c|c|c|c|c|}
\hline Lifetime & Author & Year & $\mathbf{N}$ & Age (Years) & DHA & Outcome \\
\hline \multicolumn{7}{|l|}{ Childhood } \\
\hline & Desci [3] & 2002 & 80 ठૈ\& & 12 & Plasma phospholipids ARA \& DHA & $\begin{array}{l}\text { Values of arachidonic acid and docosahexaenoic acid were } \\
\text { significantly lower in diabetic children than in controls. }\end{array}$ \\
\hline & Burrows [2] & 2011 & $48 \lesssim \&$ ठ & $\begin{array}{l}\text { Non-obese: } 9.0 \pm 0.9 \\
\text { Obese: } 8.9 \pm 1.2\end{array}$ & $\begin{array}{l}\text { Erythrocyte fatty acid; the Omega-3 } \\
\text { index (O3I) composition }\end{array}$ & $\begin{array}{l}\text { Obese children had altered erythrocyte fatty acid composition } \\
\text { unrelated to reported dietary intake. A greater proportion of } \\
\text { obese children had an omega- } 3 \text { index of }<4.0 \text { (high risk) } \\
\text { compared with non-obese children. }\end{array}$ \\
\hline & $\begin{array}{l}\text { Vasickova } \\
\text { [87] }\end{array}$ & 2011 & $120 \lesssim \& q$ (obese) & $10.0 \pm 1.9$ & $\begin{array}{c}300 \mathrm{mg} / \mathrm{day} \mathrm{DHA}+42 \mathrm{mg} / \mathrm{d} \mathrm{EPA} \\
\text { for } 3 \text { weeks }\end{array}$ & $\begin{array}{l}\text { Daily consumption of } 300 \mathrm{mg} \text { DHA and } 42 \mathrm{mg} \text { EPA for three } \\
\text { weeks leads to an improvement of the anthropometric and lipid } \\
\text { parameters in obese children [87]. }\end{array}$ \\
\hline & $\begin{array}{l}\text { Juarez Lopez } \\
\text { [89] }\end{array}$ & 2013 & $\begin{array}{l}201 \delta \& \text { (obese } \\
\text { and insulin } \\
\text { resistant) }\end{array}$ & $11.6 \pm 0.7$ & $\begin{array}{l}12 \text { weeks LC-PUFA } \\
\text { supplementation, } 360 \text { mg EPA \& } \\
240 \mathrm{mg} \text { DHA daily }\end{array}$ & $\begin{array}{l}\text { LC-PUFA supplementation for } 12 \text { weeks decreased the } \\
\text { concentrations of glucose, insulin, triglyceride-levels and BMI. }\end{array}$ \\
\hline & $\begin{array}{c}\text { Damsgaardt } \\
{[88]} \\
\end{array}$ & 2013 & $73 ठ \& \&$ & $10.29 \pm 0.58$ & Plasma DHA \&EPA concentrations & $\begin{array}{l}\text { DHA was positively associated with mean arterial pressure } \\
\text { in boys. }\end{array}$ \\
\hline \multicolumn{7}{|c|}{ Adolescence } \\
\hline & $\begin{array}{l}\text { Dangardt } \\
\text { [92] }\end{array}$ & 2012 & $25 \lesssim \& q$ & $\begin{array}{l}15.6 \pm 0.9 \text { ○ } \\
15.7 \pm 1.0 \curvearrowright\end{array}$ & $\begin{array}{l}\text { 1,2 g/d LC-PUFAs (DHA \& EPA) } \\
\text { for } 3 \text { months }\end{array}$ & $\begin{array}{l}\text { Three months of supplementation of omega-3 LCPUFA } \\
\text { improved glucose and insulin homeostasis in obese girls } \\
\text { without influencing body weight. }\end{array}$ \\
\hline \multicolumn{7}{|l|}{ Adulthood } \\
\hline & $\begin{array}{l}\text { Rivellese } \\
\text { [107] }\end{array}$ & 1997 & $\begin{array}{l}16 \bigcirc \& \text { (NIDDM } \\
\text { patients with } \\
\text { hypertriglyeridemia) }\end{array}$ & $56.0 \pm 3.0$ & $\begin{array}{l}\text { First two months: } 0.96 \mathrm{gr} \text { EPA and } \\
1.59 \text { g DHA per day Last four } \\
\text { months: } 0.64 \text { gr EPA and } 1.06 \mathrm{gr} \\
\text { DHA per day }\end{array}$ & $\begin{array}{l}\text { DHA and EPA significantly reduced plasma triglycerides and } \\
\text { VLDL- triglycerides without significant changes in blood } \\
\text { glucose control. }\end{array}$ \\
\hline
\end{tabular}


Table 1. Cont.

\begin{tabular}{|c|c|c|c|c|c|}
\hline Mori [105] & 1999 & $\begin{array}{c}56 \hat{\jmath} \text { (overweight \& } \\
\text { hyperlipidemic) }\end{array}$ & $49.1 \pm 1.2$ & $\begin{array}{l}4 \mathrm{~g} / \text { day DHA, EPA or olive oil } \\
\text { (placebo) for } 6 \text { weeks }\end{array}$ & $\begin{array}{l}\text { Purified DHA but not EPA reduced ambulatory BP and HR in } \\
\text { mildly hyperlipidemic men. }\end{array}$ \\
\hline Mori [104] & 2000 & $\begin{array}{c}59 \widehat{\jmath} \text { (overweight \& } \\
\text { hyperlipidemic) }\end{array}$ & $50.6 \pm 1.4$ & $\begin{array}{l}4 \mathrm{~g} / \text { day DHA, EPA or olive oil } \\
\text { (placebo) for } 6 \text { weeks }\end{array}$ & $\begin{array}{l}\text { DHA enhances vasodilator mechanisms and attenuates } \\
\text { constrictor responses in the forearm microcirculation. }\end{array}$ \\
\hline $\begin{array}{l}\text { Woodman } \\
\text { [102] }\end{array}$ & 2003 & $\begin{array}{l}\hat{\jmath} \& q \\
\text { (Hypertensive and } \\
\text { diabetic) }\end{array}$ & $40-75$ & $\begin{array}{l}4 \mathrm{~g} / \text { day DHA, EPA or olive oil } \\
\text { (placebo) for } 6 \text { weeks }\end{array}$ & DHA increased low density lipoprotein particle size \\
\hline Kelley [106] & 2007 & $34 \hat{\jmath}$ & $55.0 \pm 2.0$ & 7.5 g DHA-oil for 90 days & $\begin{array}{l}\text { DHA supplementation for } 45 \mathrm{~d} \text { significantly decreased } \\
\text { concentrations of fasting triacylglycerol, large VLDL, and } \\
\text { intermediate-density lipoproteins and the mean diameter of } \\
\text { VLDL particles. }\end{array}$ \\
\hline $\begin{array}{l}\text { Sneddon } \\
{[108]}\end{array}$ & 2008 & $69 \hat{\sigma}$ & $32.4 \pm 2.3$ & $\begin{array}{c}3 \mathrm{~g} / \text { day CLA }+3 \mathrm{~g} / \text { day omega- } 3 \\
\text { LC-PUFAs }\end{array}$ & $\begin{array}{l}\text { Supplementation with conjugated linoleic acids (CLAs) plus } \\
\text { omega-3 LC-PUFAs prevents increased abdominal fat mass } \\
\text { and raises fat-free mass and adiponectin levels in obese adults }\end{array}$ \\
\hline Micallef [6] & 2009 & $124 \lesssim \&$ ○ & $43.79 \pm 2.22$ & Plasma levels of DHA \& EPA & $\begin{array}{l}\text { BMI, waist circumference and hip circumference were } \\
\text { inversely correlated with } n-3 \text { PUFA, EPA and DHA ( } p<0.05 \\
\text { for all) in the obese group. Obese individuals had significantly } \\
\text { lower plasma concentrations of total } n-3 \text { PUFA, compared } \\
\text { with healthy-weight individuals. }\end{array}$ \\
\hline Stirban $[98]$ & 2010 & $34 \lesssim \& q(\mathrm{~T} 2 \mathrm{DM})$ & $56.8 \pm 8.3$ & $2 \mathrm{~g} / \mathrm{d}$ EPA \& DHA for 6 weeks & $\begin{array}{l}\text { Six weeks of supplementation with LC-PUFAs reduced the } \\
\text { postprandial decrease in macrovascular function relative to } \\
\text { placebo. LC-PUFAs supplementation improved postprandial } \\
\text { microvascular function. }\end{array}$ \\
\hline
\end{tabular}


Table 1. Cont.

Itariu [109] $\quad 2012 \quad 55 \delta \&$ (obese) $\quad 39.0 \pm 2.0 \quad 3,36 \mathrm{~g} / \mathrm{d}$ EPA \& DHA for 8 weeks

$\begin{array}{lll}\text { Labonte [96] } & 2013 \quad \begin{array}{c}12 \precsim \text { (obese } \\ +\mathrm{T} 2 \mathrm{DM})\end{array} & 54.1 \pm 7.2\end{array} \quad 3 \mathrm{~g} / \mathrm{d}$ EPA \& DHA for 8 weeks

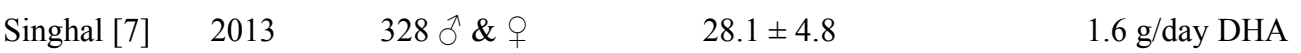

$n$-3 PUFAs, which was well tolerated, decreased the gene expression of most analyzed inflammatory genes in subcutaneous adipose tissue $(p<0.05)$ and increased production of anti-inflammatory eicosanoids in visceral adipose tissue and subcutaneous adipose tissue $(p<0.05)$. In obese patients with T2DM, EPA\&DHA supplementation did not affect the gene expression of pro-inflammatory cytokines in duodenal cells.

DHA supplementation did not improve endothelial function in healthy adolescents. Only triglyceride and very low-density lipoprotein concentrations were significant lower in DHA-supplemented individuals compared with controls.

\begin{tabular}{|c|c|c|c|c|c|}
\hline & & & & & 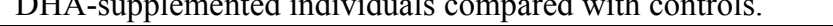 \\
\hline $\begin{array}{l}\text { McDonald } \\
\text { [101] }\end{array}$ & 2013 & $\begin{array}{c}22 \lesssim \& \uparrow \\
\text { Hypertensive and } \\
\text { T2DM }\end{array}$ & $58.6 \pm 8.8$ & $\begin{array}{l}\text { Daily supplementation of } 1.8 \mathrm{~g} \mathrm{EPA} \\
\text { and } 1.5 \mathrm{~g} \mathrm{DHA} \text { for } 8 \text { weeks }\end{array}$ & $\begin{array}{l}\text { LC-PUFAs diminish platelet superoxide production in T2DM } \\
\text { hypertensive patients in vivo. }\end{array}$ \\
\hline Virtanen [99] & 2013 & $2122 \widehat{\partial}$ & $53.1 \pm 5.1$ & Serum levels DHA, EPA, DPA & $\begin{array}{l}\text { Men with higher serum level of EPA+DHA+DPA had a 33\% } \\
\text { lower multivariate-adjusted risk for T2DM. (Trend: } p=0.01 \text { ) }\end{array}$ \\
\hline \multicolumn{6}{|l|}{ Mature and late adulthood } \\
\hline $\begin{array}{l}\text { Woodman } \\
\text { [100] }\end{array}$ & 2003 & $\begin{array}{c}51(39-\widehat{\jmath} \& 12-q) \\
\text { (Hypertensive and } \\
\text { diabetic) }\end{array}$ & $61.2 \pm 1.2$ & $\begin{array}{l}4 \mathrm{~g} / \text { day DHA, EPA or olive oil } \\
\text { (placebo) for } 6 \text { weeks }\end{array}$ & $\begin{array}{l}\text { DHA supplementation significantly reduced collagen } \\
\text { aggregation and collagen-stimulated thromboxane release. }\end{array}$ \\
\hline
\end{tabular}


Table 1. Cont.

\begin{tabular}{|c|c|c|c|c|c|}
\hline $\begin{array}{c}\text { Lemaitre } \\
\text { [122] }\end{array}$ & 2003 & $\begin{array}{l}\text { 54: Ischemic heart } \\
\text { disease } \\
\text { 125:non-fatal } \\
\text { myocardial } \\
\text { infarction } \\
\text { 179: matched } \\
\text { controls } \hat{\jmath} \& q \\
\end{array}$ & $79.1 \pm 7.5$ & DHA \& EPA plasma phospholipids & $\begin{array}{l}\text { Higher combined dietary intake of DHA and EPA, and } \\
\text { possibly } \alpha \text {-linolenic acid, may lower the risk of fatal ischemic } \\
\text { heart disease in older adults. }\end{array}$ \\
\hline $\begin{array}{c}\text { Tsitouras } \\
\text { [123] }\end{array}$ & 2008 & $12 \widehat{\delta} \&$ q & $66.1 \pm 4.5$ & $\begin{array}{c}\text { Supplemented with } 4 \mathrm{~g} / \text { day EPA } \\
\text { and DHA }\end{array}$ & $\begin{array}{l}\text { Insulin sensitivity increased significantly after } 8 \text { weeks on the } \\
\text { EPA- and DHA-diet, and serum C-reactive protein was } \\
\text { significantly reduced. }\end{array}$ \\
\hline $\begin{array}{c}\text { Heine-Böring } \\
{[5]}\end{array}$ & 2010 & $\begin{array}{c}1570\left(686-{ }^{\widehat{O}} \&\right. \\
884-9)\end{array}$ & $\begin{array}{c}64.0 \pm 5.42-\hat{0} \\
64.0 \pm 5.6-q\end{array}$ & $\begin{array}{l}\text { Food intake questionnaire; Dutch } \\
\text { food composition table (DHA \& } \\
\text { EPA levels) }\end{array}$ & $\begin{array}{l}\text { Subjects with a fish intake }>19 \mathrm{~g} / \mathrm{d} \text { had a significantly lower } \\
\text { prevalence of mild/moderate calcification. EPA plus DHA } \\
\text { intake showed no significant associations. }\end{array}$ \\
\hline Djousse [48] & 2011 & 3088 ठ \& + & 75.0 & $\begin{array}{c}\text { Plasma phospholipids DHA } \\
\text { and EPA }\end{array}$ & $\begin{array}{l}\text { DHA is not associated with a higher incidence of T2DM, and } \\
\text { individuals with higher EPA and DHA plasma concentrations } \\
\text { had lower risk on T2DM. }\end{array}$ \\
\hline
\end{tabular}

DHA: docosahexaenoic acid; EPA: eicosapentaenoic acid; DPA: docosapentaenoic acid; CLA: conjugated linoleic acids; CHF: congestive heart failure; T2DM: diabetes mellitus type 2; NIDDM: non-insulin-dependent diabetes mellitus; VLDL: very-low-density-lipoprotein; N: number of participants; Age is represented in years and in Mean \pm SD. Mean age $>4$ and $\leq 12$ Year $\rightarrow$ childhood; Mean age $>12$ and $\leq 21 \rightarrow$ adolescence; Mean age $>21$ and $\leq 60 \rightarrow$ adulthood; Mean age $>60 \rightarrow$ middle and late adulthood. 


\subsection{DHA and Metabolic Diseases in Mature and Late Adulthood}

Prevalence of metabolic diseases increases with age. Manzato et al., for example, described that in Northern Italy metabolic diseases are present in $25.6 \%$ of elder men and in $48.1 \%$ of elder women [124]. Moreover, their prevalence was mainly due to high blood pressure (93\% in both sexes) and to abdominal obesity (in 73\% of women) [124]. The prevalence of cardiovascular diseases was significantly higher among subjects diagnosed with metabolic diseases [124]. Moreover, Czernichow et al. suggested that BMI was inversely correlated with resting capillary density, which suggests a lower baseline tissue perfusion; an association with higher vasomotor tone in overweight in the elderly [125].

The incidence of T2DM in older individuals was not associated with DHA plasma phospholipid levels [48] (Table 1). However, Tsitouras and colleagues reported that following a DHA and EPA diet for a period of eight weeks significantly increased insulin sensitivity in the elderly [123]. Omega-3 LC-PUFA consumption can provide protection against cardiovascular disease by improving vasoactivity, and decreasing blood pressure and inflammation. It was shown that a higher plasma concentration of DHA, EPA and DPA in older adults is associated with lower systolic blood pressure, pulse pressure and congestive heart failure (CHF), but not with diastolic blood pressure $[50,126]$. In addition, a higher combined DHA and EPA plasma phospholipids level was associated with a lower risk of fatal ischemic heart disease [122]. DHA supplementation significantly reduced collagen aggregation and collagen-stimulated thromboxane release, which indicates that highly purified DHA may be a more effective anti-thrombotic agent than EPA [100]. Furthermore, it was reported that healthy elderly people with a higher fish intake had a significantly lower prevalence of moderate coronary calcification [5]. On the other hand, intake of EPA plus DHA showed no significant associations [5]. These findings indicate that not only DHA is associated with a reduction of cardiovascular risk factors. It is a combination of these omega-3 fatty acids, DHA, EPA and DPA that seems to provide these beneficial effects on vascular health.

\section{Conclusions}

Omega-3 LC-PUFA supplementation in children and adolescents showed beneficial effects on reducing pathological characteristics in obesity, T2DM and CVD by decreasing adipocyte differentiation, increasing adipocyte apoptosis, promoting lipolysis, improving endothelial function, lowering blood pressure, decreasing inflammation, improving glucose tolerance and decreasing BMI $[2,3,92,127,128]$. Moreover, omega-3 LC-PUFAs reduce obesity symptoms and improve vascular health in adults and the elderly. Nevertheless, the impact of DHA can be ambiguous, and is affected by differences in age, gender, and health. Other limitations are found in differences in DHA dosing; concentrations differ between human studies, which makes comparison of research findings difficult.

DHA can spontaneously be converted via non-enzymatic oxidation by reactive oxygen species into neuroprostanes, isoprostanes, isofuranes, alkenes, alkanes and aldehydes (Figure 1). These lipid peroxides, previously thought to have a harmful effect on cells, can activate gene expression changes via peroxisome proliferator-activated receptors (PPARs) and nuclear factor-like 2 (Nfr2). In addition, these molecules can also have a direct influence on ion-channel conductance, activity of proteins/enzymes via carbonyl modification, inhibition of adhesion and atherosclerosis progression [129-134]. These recent findings 
emphasize a need for multi-nutrient diets, for example LC-PUFAs combined with vitamins and anti-oxidants. These dietary factors could inhibit or stimulate the molecular processes as described and, therefore, reinforce each other's beneficial effects in an optimal combination. So, future research should focus on determining this optimal DHA-dose, depending on age and gender, and, secondly, combinations of several dietary factors like LC-PUFAs and anti-oxidants should be examined. In addition, a multi-nutrient diet could establish a multifactorial approach on inflammation and vasodilation, for instance.

DHA has been suggested to play a role in the prevention and better management of obesity, T2DM and cardiovascular disease. Recently, several studies have revealed that obesity, T2DM and CVD are correlated with the risk of dementia and AD in later life [135-139]. Therefore, DHA may protect against cognitive decline via two pathways; firstly, by reducing the development of diseases like obesity, T2DM and CVD. Secondly, by protecting against cognitive decline via maintaining membrane fluidity, increasing synaptogenesis, stimulating neurogenesis, decreasing neuroinflammation and improving cerebral blood flow [54,62,75,83,84,98,110-120]. Metabolic diseases like obesity, CVD and T2DM significantly and independently increase the risk of neurodegeneration and are therefore risk factors in the development of dementia and AD [140-142].

Further understanding is needed to define optimal doses per age and sex, in order to target these different metabolic diseases and to assess the relative efficiency of omega-3 LC-PUFAs, specifically DHA. Taken altogether, DHA could be one of the dietary protectors throughout a lifetime.

\section{Acknowledgments}

This study was supported by the EU 7th framework LipiDiDiet project (FP7/2007-2013) under grant agreement no211696.

\section{Conflicts of Interest}

The authors declare no conflict of interest.

\section{References}

1. Balakumar, P.; Taneja, G. Fish oil and vascular endothelial protection: Bench to bedside. Free Radic. Biol. Med. 2012, 53, 271-279.

2. Burrows, T.; Collins, C.E.; Garg, M.L. Omega-3 index, obesity and insulin resistance in children. Int. J. Pediatr. Obes. 2011, 6, e532-e539.

3. Decsi, T.; Minda, H.; Hermann, R.; Kozari, A.; Erhardt, E.; Burus, I.; Molnar, S.; Soltesz, G. Polyunsaturated fatty acids in plasma and erythrocyte membrane lipids of diabetic children. Prostaglandins Leukot. Essent. Fatty Acids 2002, 67, 203-210.

4. Egert, S.; Stehle, P. Impact of $n-3$ fatty acids on endothelial function: Results from human interventions studies. Curr. Opin. Clin. Nutr. Metab. Care 2011, 14, 121-131.

5. Heine-Broring, R.C.; Brouwer, I.A.; Proenca, R.V.; van Rooij, F.J.; Hofman, A.; Oudkerk, M.; Witteman, J.C.; Geleijnse, J.M. Intake of fish and marine $n-3$ fatty acids in relation to coronary calcification: The rotterdam study. Am. J. Clin. Nutr. 2010, 91, 1317-1323. 
6. Micallef, M.; Munro, I.; Phang, M.; Garg, M. Plasma $n-3$ polyunsaturated fatty acids are negatively associated with obesity. Br. J. Nutr. 2009, 102, 1370-1374.

7. Singhal, A.; Lanigan, J.; Storry, C.; Low, S.; Birbara, T.; Lucas, A.; Deanfield, J. Docosahexaenoic acid supplementation, vascular function and risk factors for cardiovascular disease: A randomized controlled trial in young adults. J. Am. Heart Assoc. 2013, 2, e000283.

8. Singh, M. Essential fatty acids, dha and human brain. Indian J. Pediatr. 2005, 72, 239-242.

9. Clandinin, M.T.; Jumpsen, J.; Suh, M. Relationship between fatty acid accretion, membrane composition, and biologic functions. J. Pediatr. 1994, 125, S25-S32.

10. Petrie, J.R.; Shrestha, P.; Liu, Q.; Mansour, M.P.; Wood, C.C.; Zhou, X.R.; Nichols, P.D.; Green, A.G.; Singh, S.P. Rapid expression of transgenes driven by seed-specific constructs in leaf tissue: Dha production. Plant Methods 2010, 6, 8 .

11. Moore, S.A. Polyunsaturated fatty acid synthesis and release by brain-derived cells in vitro. J. Mol. Neurosci. 2001, 16, 195-200.

12. Demar, J.C., Jr.; Ma, K.; Chang, L.; Bell, J.M.; Rapoport, S.I. Alpha-linolenic acid does not contribute appreciably to docosahexaenoic acid within brain phospholipids of adult rats fed a diet enriched in docosahexaenoic acid. J. Neurochem. 2005, 94, 1063-1076.

13. Hashimoto, M.; Tanabe, Y.; Fujii, Y.; Kikuta, T.; Shibata, H.; Shido, O. Chronic administration of docosahexaenoic acid ameliorates the impairment of spatial cognition learning ability in amyloid beta-infused rats. J. Nutr. 2005, 135, 549-555.

14. Suzuki, H.; Park, S.J.; Tamura, M.; Ando, S. Effect of the long-term feeding of dietary lipids on the learning ability, fatty acid composition of brain stem phospholipids and synaptic membrane fluidity in adult mice: A comparison of sardine oil diet with palm oil diet. Mech. Ageing Dev. 1998, $101,119-128$.

15. Shinohara, M.; Mirakaj, V.; Serhan, C.N. Functional metabolomics reveals novel active products in the dha metabolome. Front. Immunol. 2012, 3, 81.

16. Serhan, C.N.; Hong, S.; Gronert, K.; Colgan, S.P.; Devchand, P.R.; Mirick, G.; Moussignac, R.L. Resolvins: A family of bioactive products of omega-3 fatty acid transformation circuits initiated by aspirin treatment that counter proinflammation signals. J. Exp. Med. 2002, 196, 1025-1037.

17. Serhan, C.N.; Yang, R.; Martinod, K.; Kasuga, K.; Pillai, P.S.; Porter, T.F.; Oh, S.F.; Spite, M. Maresins: Novel macrophage mediators with potent antiinflammatory and proresolving actions. J. Exp. Med. 2009, 206, 15-23.

18. Serhan, C.N. Systems approach with inflammatory exudates uncovers novel anti-inflammatory and pro-resolving mediators. Prostaglandins Leukot. Essent. Fatty Acids 2008, 79, 157-163.

19. Serhan, C.N.; Petasis, N.A. Resolvins and protectins in inflammation resolution. Chem. Rev. 2011, $111,5922-5943$.

20. Kris-Etherton, P.M.; Harris, W.S.; Appel, L.J. Fish consumption, fish oil, omega-3 fatty acids, and cardiovascular disease. Circulation 2002, 106, 2747-2757.

21. Torpy, J.M.; Lynm, C.; Glass, R.M. Jama patient page. Eating fish: Health benefits and risks. JAMA 2006, 296, 1926.

22. Bradbury, J. Docosahexaenoic acid (DHA): An ancient nutrient for the modern human brain. Nutrients 2011, 3, 529-554. 
23. Cossins, A.R.; Macdonald, A.G. The adaptation of biological membranes to temperature and pressure: Fish from the deep and cold. J. Bioenerg. Biomembr. 1989, 21, 115-135.

24. Luchtman, D.W.; Song, C. Cognitive enhancement by omega-3 fatty acids from child-hood to old age: Findings from animal and clinical studies. Neuropharmacology 2013, 64, 550-565.

25. Bousquet, M.; Saint-Pierre, M.; Julien, C.; Salem, N., Jr.; Cicchetti, F.; Calon, F. Beneficial effects of dietary omega-3 polyunsaturated fatty acid on toxin-induced neuronal degeneration in an animal model of parkinson's disease. FASEB J. 2008, 22, 1213-1225.

26. Chytrova, G.; Ying, Z.; Gomez-Pinilla, F. Exercise contributes to the effects of DHA dietary supplementation by acting on membrane-related synaptic systems. Brain Res. 2010, 1341, 32-40.

27. Hashimoto, M.; Hossain, S.; Shimada, T.; Shido, O. Docosahexaenoic acid-induced protective effect against impaired learning in amyloid beta-infused rats is associated with increased synaptosomal membrane fluidity. Clin. Exp. Pharmacol. Physiol. 2006, 33, 934-939.

28. Teague, W.E.; Fuller, N.L.; Rand, R.P.; Gawrisch, K. Polyunsaturated lipids in membrane fusion events. Cell. Mol. Biol. Lett. 2002, 7, 262-264.

29. Ouellet, M.; Emond, V.; Chen, C.T.; Julien, C.; Bourasset, F.; Oddo, S.; LaFerla, F.; Bazinet, R.P.; Calon, F. Diffusion of docosahexaenoic and eicosapentaenoic acids through the blood-brain barrier: An in situ cerebral perfusion study. Neurochem. Int. 2009, 55, 476-482.

30. Hamilton, J.A. Fast flip-flop of cholesterol and fatty acids in membranes: Implications for membrane transport proteins. Curr. Opin. Lipidol. 2003, 14, 263-271.

31. Doege, H.; Stahl, A. Protein-mediated fatty acid uptake: Novel insights from in vivo models. Physiology 2006, 21, 259-268.

32. Nikolakopoulou, Z.; Shaikh, M.H.; Dehlawi, H.; Michael-Titus, A.T.; Parkinson, E.K. The induction of apoptosis in pre-malignant keratinocytes by omega-3 polyunsaturated fatty acids docosahexaenoic acid (DHA) and eicosapentaenoic acid (EPA) is inhibited by albumin. Toxicol. Lett. 2013, 218, 150-158.

33. Coburn, C.T.; Hajri, T.; Ibrahimi, A.; Abumrad, N.A. Role of CD36 in membrane transport and utilization of long-chain fatty acids by different tissues. J. Mol. Neurosci. 2001, 16, 117-121.

34. Gargiulo, C.E.; Stuhlsatz-Krouper, S.M.; Schaffer, J.E. Localization of adipocyte long-chain fatty acyl-coa synthetase at the plasma membrane. J. Lipid Res. 1999, 40, 881-892.

35. Kazantzis, M.; Stahl, A. Fatty acid transport proteins, implications in physiology and disease. Biochim. Biophys. Acta 2012, 1821, 852-857.

36. Knudsen, J.; Neergaard, T.B.; Gaigg, B.; Jensen, M.V.; Hansen, J.K. Role of acyl-CoA binding protein in acyl-CoA metabolism and acyl-CoA-mediated cell signaling. J. Nutr. 2000, 130, 294S-298S.

37. Storch, J.; McDermott, L. Structural and functional analysis of fatty acid-binding proteins. J. Lipid Res. 2009, 50 (Suppl.), S126-S131.

38. Storch, J.; Thumser, A.E. Tissue-specific functions in the fatty acid-binding protein family. J. Biol. Chem. 2010, 285, 32679-32683.

39. Glatz, J.F.; Luiken, J.J.; van Bilsen, M.; van der Vusse, G.J. Cellular lipid binding proteins as facilitators and regulators of lipid metabolism. Mol. Cell. Biochem. 2002, 239, 3-7.

40. Khnykin, D.; Miner, J.H.; Jahnsen, F. Role of fatty acid transporters in epidermis: Implications for health and disease. Dermato-Endocrinology 2011, 3, 53-61. 
41. WHO. Obesity and Overweight. Available online: http://www.who.int/mediacentre/factsheets /fs311/en/index.html (accessed on 9 August 2012).

42. Van Greevenbroek, M.M.; Schalkwijk, C.G.; Stehouwer, C.D. Obesity-associated low-grade inflammation in type 2 diabetes mellitus: Causes and consequences. Neth. J. Med. 2013, 71, 174-187.

43. Bender, S.B.; McGraw, A.P.; Jaffe, I.Z.; Sowers, J.R. Mineralocorticoid receptor-mediated vascular insulin resistance: An early contributor to diabetes-related vascular disease? Diabetes 2013, 62, 313-319.

44. Lean, M.E. Obesity: Burdens of illness and strategies for prevention or management. Drugs Today (Barc.) 2000, 36, 773-784.

45. Andersson, C.X.; Gustafson, B.; Hammarstedt, A.; Hedjazifar, S.; Smith, U. Inflamed adipose tissue, insulin resistance and vascular injury. Diabetes Metab. Res. Rev. 2008, 24, 595-603.

46. Morrish, N.J.; Wang, S.L.; Stevens, L.K.; Fuller, J.H.; Keen, H. Mortality and causes of death in the who multinational study of vascular disease in diabetes. Diabetologia 2001, 44, S14-S21.

47. Dangardt, F.; Osika, W.; Chen, Y.; Nilsson, U.; Gan, L.M.; Gronowitz, E.; Strandvik, B.; Friberg, P. Omega-3 fatty acid supplementation improves vascular function and reduces inflammation in obese adolescents. Atherosclerosis 2010, 212, 580-585.

48. Djousse, L.; Biggs, M.L.; Lemaitre, R.N.; King, I.B.; Song, X.; Ix, J.H.; Mukamal, K.J.; Siscovick, D.S.; Mozaffarian, D. Plasma omega-3 fatty acids and incident diabetes in older adults. Am. J. Clin. Nutr. 2011, 94, 527-533.

49. Mozaffarian, D.; Lemaitre, R.N.; King, I.B.; Song, X.; Huang, H.; Sacks, F.M.; Rimm, E.B.; Wang, M.; Siscovick, D.S. Plasma phospholipid long-chain omega-3 fatty acids and total and cause-specific mortality in older adults: A cohort study. Ann. Intern. Med. 2013, 158, 515-525.

50. Mozaffarian, D.; Lemaitre, R.N.; King, I.B.; Song, X.; Spiegelman, D.; Sacks, F.M.; Rimm, E.B.; Siscovick, D.S. Circulating long-chain omega-3 fatty acids and incidence of congestive heart failure in older adults: The cardiovascular health study: A cohort study. Ann. Intern. Med. 2011, 155, $160-170$.

51. Antuna-Puente, B.; Feve, B.; Fellahi, S.; Bastard, J.P. Adipokines: The missing link between insulin resistance and obesity. Diabetes Metab. 2008, 34, 2-11.

52. Garcia, C.; Feve, B.; Ferre, P.; Halimi, S.; Baizri, H.; Bordier, L.; Guiu, G.; Dupuy, O.; Bauduceau, B.; Mayaudon, H. Diabetes and inflammation: Fundamental aspects and clinical implications. Diabetes Metab. 2010, 36, 327-338.

53. Gonzalez-Periz, A.; Horrillo, R.; Ferre, N.; Gronert, K.; Dong, B.; Moran-Salvador, E.; Titos, E.; Martinez-Clemente, M.; Lopez-Parra, M.; Arroyo, V.; et al. Obesity-induced insulin resistance and hepatic steatosis are alleviated by omega-3 fatty acids: A role for resolvins and protectins. FASEB J. 2009, 23, 1946-1957.

54. Hoshi, T.; Wissuwa, B.; Tian, Y.; Tajima, N.; Xu, R.; Bauer, M.; Heinemann, S.H.; Hou, S. Omega-3 fatty acids lower blood pressure by directly activating large-conductance $\mathrm{Ca}^{2+}$-dependent $\mathrm{K}^{+}$channels. Proc. Natl. Acad. Sci. USA 2013, 110, 4816-4821.

55. Kim, Y.J.; Kim, O.Y.; Cho, Y.; Chung, J.H.; Jung, Y.S.; Hwang, G.S.; Shin, M.J. Plasma phospholipid fatty acid composition in ischemic stroke: Importance of docosahexaenoic acid in the risk for intracranial atherosclerotic stenosis. Atherosclerosis 2012, 225, 418-424. 
56. Pickup, J.C.; Mattock, M.B.; Chusney, G.D.; Burt, D. Niddm as a disease of the innate immune system: Association of acute-phase reactants and interleukin-6 with metabolic syndrome X. Diabetologia 1997, 40, 1286-1292.

57. Feve, B.; Bastard, J.P. The role of interleukins in insulin resistance and type 2 diabetes mellitus. Nat. Rev. Endocrinol. 2009, 5, 305-311.

58. Bhagat, K.; Vallance, P. Inflammatory cytokines impair endothelium-dependent dilatation in human veins in vivo. Circulation 1997, 96, 3042-3047.

59. Wang, P.; Ba, Z.F.; Chaudry, I.H. Administration of tumor necrosis factor-alpha in vivo depresses endothelium-dependent relaxation. Am. J. Physiol. 1994, 266, H2535-H2541.

60. Das, U.N. Is obesity an inflammatory condition? Nutrition 2001, 17, 953-966.

61. Murumalla, R.K.; Gunasekaran, M.K.; Padhan, J.K.; Bencharif, K.; Gence, L.; Festy, F.; Cesari, M.; Roche, R.; Hoareau, L. Fatty acids do not pay the toll: Effect of sfa and pufa on human adipose tissue and mature adipocytes inflammation. Lipids Health Dis. 2012, 11, 175.

62. Titos, E.; Rius, B.; Gonzalez-Periz, A.; Lopez-Vicario, C.; Moran-Salvador, E.; Martinez-Clemente, M.; Arroyo, V.; Claria, J. Resolvin d1 and its precursor docosahexaenoic acid promote resolution of adipose tissue inflammation by eliciting macrophage polarization toward an m2-like phenotype. J. Immunol. 2011, 187, 5408-5418.

63. Bonadonna, R.C.; Groop, L.; Kraemer, N.; Ferrannini, E.; del Prato, S.; deFronzo, R.A. Obesity and insulin resistance in humans: A dose-response study. Metabolism 1990, 39, 452-459.

64. Steinberger, J.; Daniels, S.R.; American Heart Association Atherosclerosis, Hypertension; Obesity in the Young Committee; American Heart Association Diabetes Committee. Obesity, insulin resistance, diabetes, and cardiovascular risk in children: An american heart association scientific statement from the atherosclerosis, hypertension, and obesity in the young committee (council on cardiovascular disease in the young) and the diabetes committee (council on nutrition, physical activity, and metabolism). Circulation 2003, 107, 1448-1453.

65. Makni, E.; Moalla, W.; Lac, G.; Aouichaoui, C.; Cannon, D.; Elloumi, M.; Tabka, Z. The homeostasis model assessment-adiponectin (HOMA-AD) is the most sensitive predictor of insulin resistance in obese children. Ann. Endocrinol. (Paris) 2012, 73, 26-33.

66. Stienstra, R.; Tack, C.J.; Kanneganti, T.D.; Joosten, L.A.; Netea, M.G. The inflammasome puts obesity in the danger zone. Cell Metab. 2012, 15, 10-18.

67. Bastard, J.P.; Maachi, M.; Van Nhieu, J.T.; Jardel, C.; Bruckert, E.; Grimaldi, A.; Robert, J.J.; Capeau, J.; Hainque, B. Adipose tissue IL-6 content correlates with resistance to insulin activation of glucose uptake both in vivo and in vitro. J. Clin. Endocrinol. Metab. 2002, 87, 2084-2089.

68. Botton, J.; Heude, B.; Kettaneh, A.; Borys, J.M.; Lommez, A.; Bresson, J.L.; Ducimetiere, P.; Charles, M.A. Cardiovascular risk factor levels and their relationships with overweight and fat distribution in children: The Fleurbaix Laventie Ville Sante II study. Metabolism 2007, 56, 614-622.

69. Dandona, P.; Aljada, A.; Bandyopadhyay, A. Inflammation: The link between insulin resistance, obesity and diabetes. Trends Immunol. 2004, 25, 4-7.

70. Johansson, S.; Wilhelmsen, L.; Welin, C.; Eriksson, H.; Welin, L.; Rosengren, A. Obesity, smoking and secular trends in cardiovascular risk factors in middle-aged women: Data from population studies in goteborg from 1980 to 2003. J. Intern. Med. 2010, 268, 594-603.

71. Kopelman, P.G. Obesity as a medical problem. Nature 2000, 404, 635-643. 
72. Poirier, P.; Giles, T.D.; Bray, G.A.; Hong, Y.; Stern, J.S.; Pi-Sunyer, F.X.; Eckel, R.H. Obesity and cardiovascular disease: Pathophysiology, evaluation, and effect of weight loss. Arterioscler. Thromb. Vasc. Biol. 2006, 26, 968-976.

73. Sorisky, A. Molecular links between obesity and cardiovascular disease. Am. J. Ther. 2002, 9, $516-521$.

74. Kim, H.K.; Della-Fera, M.; Lin, J.; Baile, C.A. Docosahexaenoic acid inhibits adipocyte differentiation and induces apoptosis in 3T3-L1 preadipocytes. J. Nutr. 2006, 136, 2965-2969.

75. Bang, H.O.; Dyerberg, J.; Hjoorne, N. The composition of food consumed by greenland eskimos. Acta Med. Scand. 1976, 200, 69-73.

76. Calo, L.; Bianconi, L.; Colivicchi, F.; Lamberti, F.; Loricchio, M.L.; de Ruvo, E.; Meo, A.; Pandozi, C.; Staibano, M.; Santini, M. N-3 fatty acids for the prevention of atrial fibrillation after coronary artery bypass surgery: A randomized, controlled trial. J. Am. Coll. Cardiol. 2005, 45, 1723-1728.

77. Dallongeville, J.; Yarnell, J.; Ducimetiere, P.; Arveiler, D.; Ferrieres, J.; Montaye, M.; Luc, G.; Evans, A.; Bingham, A.; Hass, B.; et al. Fish consumption is associated with lower heart rates. Circulation 2003, 108, 820-825.

78. Singh, R.B.; Niaz, M.A.; Sharma, J.P.; Kumar, R.; Rastogi, V.; Moshiri, M. Randomized, double-blind, placebo-controlled trial of fish oil and mustard oil in patients with suspected acute myocardial infarction: The indian experiment of infarct survival-4. Cardiovasc. Drugs Ther. 1997, 11, 485-491.

79. Dietary supplementation with $n-3$ polyunsaturated fatty acids and vitamin E after myocardial infarction: Results of the gissi-prevenzione trial. Gruppo italiano per lo studio della sopravvivenza nell'infarto miocardico. Lancet 1999, 354, 447-455.

80. Lorente-Cebrian, S.; Costa, A.G.; Navas-Carretero, S.; Zabala, M.; Martinez, J.A.; Moreno-Aliaga, M.J. Role of omega-3 fatty acids in obesity, metabolic syndrome, and cardiovascular diseases: A review of the evidence. J. Physiol. Biochem. 2013, 69, 633-651.

81. Thies, F.; Garry, J.M.; Yaqoob, P.; Rerkasem, K.; Williams, J.; Shearman, C.P.; Gallagher, P.J.; Calder, P.C.; Grimble, R.F. Association of n-3 polyunsaturated fatty acids with stability of atherosclerotic plaques: A randomised controlled trial. Lancet 2003, 361, 477-485.

82. Baumann, K.H.; Hessel, F.; Larass, I.; Muller, T.; Angerer, P.; Kiefl, R.; von Schacky, C. Dietary omega-3, omega-6, and omega-9 unsaturated fatty acids and growth factor and cytokine gene expression in unstimulated and stimulated monocytes. A randomized volunteer study. Arterioscler. Thromb. Vasc. Biol. 1999, 19, 59-66.

83. Goodfellow, J.; Bellamy, M.F.; Ramsey, M.W.; Jones, C.J.; Lewis, M.J. Dietary supplementation with marine omega-3 fatty acids improve systemic large artery endothelial function in subjects with hypercholesterolemia. J. Am. Coll. Cardiol. 2000, 35, 265-270.

84. Kasbi Chadli, F.; Andre, A.; Prieur, X.; Loirand, G.; Meynier, A.; Krempf, M.; Nguyen, P.; Ouguerram, K. N-3 PUFA prevent metabolic disturbances associated with obesity and improve endothelial function in golden syrian hamsters fed with a high-fat diet. Br. J. Nutr. 2011, $107,1305-1315$. 
85. Van Emmerik, N.M.; Renders, C.M.; van de Veer, M.; van Buuren, S.; van der Baan-Slootweg, O.H.; Kist-van Holthe, J.E.; Hirasing, R.A. High cardiovascular risk in severely obese young children and adolescents. Arch. Dis. Child. 2012, 97, 818-821.

86. Salvatore, D.; Satnick, A.; Abell, R.; Messina, C.R.; Chawla, A. The prevalence of abnormal metabolic parameters in obese and overweight children. JPEN J. Parenter Enteral. Nutr. 2014, 38, 852-855.

87. Vasickova, L.; Stavek, P.; Suchanek, P. Possible effect of dha intake on body weight reduction and lipid metabolism in obese children. Neuro Endocrinol. Lett. 2011, 32 (Suppl. 2), 64-67.

88. Damsgaard, C.T.; Stark, K.D.; Hjorth, M.F.; Biltoft-Jensen, A.; Astrup, A.; Michaelsen, K.F.; Lauritzen, L. $N$-3 PUFA status in school children is associated with beneficial lipid profile, reduced physical activity and increased blood pressure in boys. Br. J. Nutr. 2013, 110, 1304-1312.

89. Juarez-Lopez, C.; Klunder-Klunder, M.; Madrigal-Azcarate, A.; Flores-Huerta, S. Omega-3 polyunsaturated fatty acids reduce insulin resistance and triglycerides in obese children and adolescents. Pediatr. Diabetes 2013, 14, 377-383.

90. Raiko, J.R.; Oikonen, M.; Wendelin-Saarenhovi, M.; Siitonen, N.; Kahonen, M.; Lehtimaki, T.; Viikari, J.; Jula, A.; Loo, B.M.; Huupponen, R.; et al. Plasminogen activator inhitor-1 associates with cardiovascular risk factors in healthy young adults in the cardiovascular risk in young finns study. Atherosclerosis 2012, 224, 208-212.

91. Yau, P.L.; Javier, D.C.; Ryan, C.M.; Tsui, W.H.; Ardekani, B.A.; Ten, S.; Convit, A. Preliminary evidence for brain complications in obese adolescents with type 2 diabetes mellitus. Diabetologia 2010, 53, 2298-2306.

92. Dangardt, F.; Chen, Y.; Gronowitz, E.; Dahlgren, J.; Friberg, P.; Strandvik, B. High physiological omega-3 fatty acid supplementation affects muscle fatty acid composition and glucose and insulin homeostasis in obese adolescents. J. Nutr. Metab. 2012, 2012, 395757.

93. Rise, P.; Tragni, E.; Ghezzi, S.; Agostoni, C.; Marangoni, F.; Poli, A.; Catapano, A.L.; Siani, A.; Iacoviello, L.; Galli, C.; et al. Different patterns characterize omega 6 and omega 3 long chain polyunsaturated fatty acid levels in blood from Italian infants, children, adults and elderly. Prostaglandins Leukot. Essent. Fatty Acids 2013, 89, 215-220.

94. Federation, I.D. IDF Diabetes Atlas. Available online: http://www.idf.org/diabetesatlas (accessed on 18 June 2014).

95. Ergotron, I. Obesity, Cardiovascular Disease and Diabetes Regional Statistics by Country/State/Province. Available online: http://www.juststand.org/Portals/3/literature/regional Stats.pdf (accessed on 2 April 2014).

96. Labonte, M.E.; Couture, P.; Tremblay, A.J.; Hogue, J.C.; Lemelin, V.; Lamarche, B. Eicosapentaenoic and docosahexaenoic acid supplementation and inflammatory gene expression in the duodenum of obese patients with type 2 diabetes. Nutr. J. 2013, 12, 98.

97. Brostow, D.P.; Odegaard, A.O.; Koh, W.P.; Duval, S.; Gross, M.D.; Yuan, J.M.; Pereira, M.A. Omega-3 fatty acids and incident type 2 diabetes: The singapore chinese health study. Am. J. Clin. Nutr. 2011, 94, 520-526.

98. Stirban, A.; Nandrean, S.; Gotting, C.; Tamler, R.; Pop, A.; Negrean, M.; Gawlowski, T.; Stratmann, B.; Tschoepe, D. Effects of $n-3$ fatty acids on macro- and microvascular function in subjects with type 2 diabetes mellitus. Am. J. Clin. Nutr. 2010, 91, 808-813. 
99. Virtanen, J.K.; Mursu, J.; Voutilainen, S.; Uusitupa, M.; Tuomainen, T.P. Serum omega-3 polyunsaturated fatty acids and risk of incident type 2 diabetes in men: The kuopio ischaemic heart disease risk factor study. Diabetes Care 2014, 37, 189-196.

100. Woodman, R.J.; Mori, T.A.; Burke, V.; Puddey, I.B.; Barden, A.; Watts, G.F.; Beilin, L.J. Effects of purified eicosapentaenoic acid and docosahexaenoic acid on platelet, fibrinolytic and vascular function in hypertensive type 2 diabetic patients. Atherosclerosis 2003, 166, 85-93.

101. McDonald, D.M.; O’Kane, F.; McConville, M.; Devine, A.B.; McVeigh, G.E. Platelet redox balance in diabetic patients with hypertension improved by $n-3$ fatty acids. Diabetes Care 2013, 36, 998-1005.

102. Woodman, R.J.; Mori, T.A.; Burke, V.; Puddey, I.B.; Watts, G.F.; Best, J.D.; Beilin, L.J. Docosahexaenoic acid but not eicosapentaenoic acid increases ldl particle size in treated hypertensive type 2 diabetic patients. Diabetes Care 2003, 26, 253.

103. Mori, T.A.; Burke, V.; Puddey, I.B.; Watts, G.F.; O’Neal, D.N.; Best, J.D.; Beilin, L.J. Purified eicosapentaenoic and docosahexaenoic acids have differential effects on serum lipids and lipoproteins, ldl particle size, glucose, and insulin in mildly hyperlipidemic men. Am. J. Clin. Nutr. 2000, 71, 1085-1094.

104. Mori, T.A.; Watts, G.F.; Burke, V.; Hilme, E.; Puddey, I.B.; Beilin, L.J. Differential effects of eicosapentaenoic acid and docosahexaenoic acid on vascular reactivity of the forearm microcirculation in hyperlipidemic, overweight men. Circulation 2000, 102, 1264-1269.

105. Mori, T.A.; Bao, D.Q.; Burke, V.; Puddey, I.B.; Beilin, L.J. Docosahexaenoic acid but not eicosapentaenoic acid lowers ambulatory blood pressure and heart rate in humans. Hypertension 1999, 34, 253-260.

106. Kelley, D.S.; Siegel, D.; Vemuri, M.; Mackey, B.E. Docosahexaenoic acid supplementation improves fasting and postprandial lipid profiles in hypertriglyceridemic men. Am. J. Clin. Nutr. 2007, 86, 324-333.

107. Rivellese, A.A.; Maffettone, A.; Iovine, C.; Di Marino, L.; Annuzzi, G.; Mancini, M.; Riccardi, G. Long-term effects of fish oil on insulin resistance and plasma lipoproteins in niddm patients with hypertriglyceridemia. Diabetes Care 1996, 19, 1207-1213.

108. Sneddon, A.A.; Tsofliou, F.; Fyfe, C.L.; Matheson, I.; Jackson, D.M.; Horgan, G.; Winzell, M.S.; Wahle, K.W.; Ahren, B.; Williams, L.M. Effect of a conjugated linoleic acid and omega-3 fatty acid mixture on body composition and adiponectin. Obesity (Silver Spring) 2008, 16, 1019-1024.

109. Itariu, B.K.; Zeyda, M.; Hochbrugger, E.E.; Neuhofer, A.; Prager, G.; Schindler, K.; Bohdjalian, A.; Mascher, D.; Vangala, S.; Schranz, M.; et al. Long-chain $n-3$ pufas reduce adipose tissue and systemic inflammation in severely obese nondiabetic patients: A randomized controlled trial. Am. J. Clin. Nutr. 2012, 96, 1137-1149.

110. Kris-Etherton, P.M.; Harris, W.S.; Appel, L.J.; AHA Nutrition Committee; American Heart Association. Omega-3 fatty acids and cardiovascular disease: New recommendations from the american heart association. Arterioscler. Thromb. Vasc. Biol. 2003, 23, 151-152.

111. Geleijnse, J.M.; Giltay, E.J.; Grobbee, D.E.; Donders, A.R.; Kok, F.J. Blood pressure response to fish oil supplementation: Metaregression analysis of randomized trials. J. Hypertens. 2002, 20, 1493-1499. 
112. Von Schacky, C.; Harris, W.S. Cardiovascular risk and the omega-3 index. J. Cardiovasc. Med. 2007, 8 (Suppl. 1), S46-S49.

113. Connor, W.E. Importance of n-3 fatty acids in health and disease. Am. J. Clin. Nutr. 2000, 71, 171S-175S.

114. Okuda, N.; Ueshima, H.; Okayama, A.; Saitoh, S.; Nakagawa, H.; Rodriguez, B.L.; Sakata, K.; Choudhury, S.R.; Curb, J.D.; Stamler, J.; et al. Relation of long chain n-3 polyunsaturated fatty acid intake to serum high density lipoprotein cholesterol among japanese men in japan and japanese-american men in hawaii: The interlipid study. Atherosclerosis 2005, 178, 371-379.

115. Leaf, A.; Kang, J.X.; Xiao, Y.F.; Billman, G.E. Clinical prevention of sudden cardiac death by $n-3$ polyunsaturated fatty acids and mechanism of prevention of arrhythmias by $n-3$ fish oils. Circulation 2003, 107, 2646-2652.

116. Harris, W.S.; Lu, G.; Rambjor, G.S.; Walen, A.I.; Ontko, J.A.; Cheng, Q.; Windsor, S.L. Influence of $n-3$ fatty acid supplementation on the endogenous activities of plasma lipases. Am. J. Clin. Nutr. 1997, 66, 254-260.

117. Calder, P.C.; Yaqoob, P. Omega-3 (n-3) fatty acids, cardiovascular disease and stability of atherosclerotic plaques. Cell. Mol. Biol. 2010, 56, 28-37.

118. Dyerberg, J.; Bang, H.O. Lipid metabolism, atherogenesis, and haemostasis in eskimos: The role of the prostaglandin-3 family. Haemostasis 1979, 8, 227-233.

119. He, K.; Song, Y.; Daviglus, M.L.; Liu, K.; Van Horn, L.; Dyer, A.R.; Greenland, P. Accumulated evidence on fish consumption and coronary heart disease mortality: A meta-analysis of cohort studies. Circulation 2004, 109, 2705-2711.

120. Janssen, C.I.; Kiliaan, A.J. Long-chain polyunsaturated fatty acids (LCPUFA) from genesis to senescence: The influence of LCPUFA on neural development, aging, and neurodegeneration. Prog. Lipid Res. 2014, 53, 1-17.

121. Cottin, S.C.; Sanders, T.A.; Hall, W.L. The differential effects of epa and dha on cardiovascular risk factors. Proc. Nutr. Soc. 2011, 70, 215-231.

122. Lemaitre, R.N.; King, I.B.; Mozaffarian, D.; Kuller, L.H.; Tracy, R.P.; Siscovick, D.S. N-3 polyunsaturated fatty acids, fatal ischemic heart disease, and nonfatal myocardial infarction in older adults: The cardiovascular health study. Am. J. Clin. Nutr. 2003, 77, 319-325.

123. Tsitouras, P.D.; Gucciardo, F.; Salbe, A.D.; Heward, C.; Harman, S.M. High omega-3 fat intake improves insulin sensitivity and reduces CRP and IL6, but does not affect other endocrine axes in healthy older adults. Horm. Metab. Res. 2008, 40, 199-205.

124. Manzato, E.; Romanato, G.; Zambon, S.; Corti, M.C.; Baggio, G.; Sartori, L.; Musacchio, E.; Zanoni, S.; Marin, R.; Crepaldi, G. Metabolic syndrome and cardiovascular disease in the elderly: The Progetto Veneto Anziani (Pro.V.A.) study. Aging Clin. Exp. Res. 2008, 20, 47-52.

125. Czernichow, S.; Greenfield, J.R.; Galan, P.; Bastard, J.P.; Charnaux, N.; Samaras, K.; Safar, M.E.; Blacher, J.; Hercberg, S.; Levy, B.I. Microvascular dysfunction in healthy insulin-sensitive overweight individuals. J. Hypertens. 2010, 28, 325-332.

126. Virtanen, J.K.; Nyantika, A.N.; Kauhanen, J.; Voutilainen, S.; Tuomainen, T.P. Serum long-chain n-3 polyunsaturated fatty acids, methylmercury and blood pressure in an older population. Hypertens. Res. 2012, 35, 1000-1004. 
127. Engler, M.M.; Engler, M.B.; Malloy, M.; Chiu, E.; Besio, D.; Paul, S.; Stuehlinger, M.; Morrow, J.; Ridker, P.; Rifai, N.; et al. Docosahexaenoic acid restores endothelial function in children with hyperlipidemia: Results from the early study. Int. J. Clin. Pharmacol. Ther. 2004, 42, 672-679.

128. Saito, E.; Okada, T.; Abe, Y.; Kuromori, Y.; Miyashita, M.; Iwata, F.; Hara, M.; Ayusawa, M.; Mugishima, H.; Kitamura, Y. Docosahexaenoic acid content in plasma phospholipids and desaturase indices in obese children. J. Atheroscler. Thromb. 2011, 18, 345-350.

129. Kalofoutis, C.; Piperi, C.; Kalofoutis, A.; Harris, F.; Phoenix, D.; Singh, J. Type II diabetes mellitus and cardiovascular risk factors: Current therapeutic approaches. Exp. Clin. Cardiol. 2007, 12, 17-28.

130. Stanley, J.C.; Elsom, R.L.; Calder, P.C.; Griffin, B.A.; Harris, W.S.; Jebb, S.A.; Lovegrove, J.A.; Moore, C.S.; Riemersma, R.A.; Sanders, T.A. UK food standards agency workshop report: The effects of the dietary $n-6: N-3$ fatty acid ratio on cardiovascular health. Br. J. Nutr. 2007, 98, 1305-1310.

131. Wan, Q.; Harris, M.F.; Powell-Davies, G.; Jayasinghe, U.W.; Flack, J.; Georgiou, A.; Burns, J.R.; Penn, D.L. Cardiovascular risk levels in general practice patients with type 2 diabetes in rural and urban areas. Aust. J. Rural Health 2007, 15, 327-333.

132. Hansen, S.N.; Harris, W.S. New evidence for the cardiovascular benefits of long chain omega-3 fatty acids. Curr. Atheroscler. Rep. 2007, 9, 434-440.

133. Wan, Q.; Harris, M.F.; Davies, G.P.; Jayasinghe, U.W.; Flack, J.; Georgiou, A.; Burns, J.R.; Penn, D.L. Cardiovascular risk management and its impact in Australian general practice patients with type 2 diabetes in urban and rural areas. Int. J. Clin. Pract. 2008, 62, 53-58.

134. Daniels, S.R.; Long, B.; Crow, S.; Styne, D.; Sothern, M.; Vargas-Rodriguez, I.; Harris, L.; Walch, J.; Jasinsky, O.; Cwik, K.; et al. Cardiovascular effects of sibutramine in the treatment of obese adolescents: Results of a randomized, double-blind, placebo-controlled study. Pediatrics 2007, 120, e147-e157.

135. Gustafson, D. Adiposity indices and dementia. Lancet Neurol. 2006, 5, 713-720.

136. Gustafson, D.R. A life course of adiposity and dementia. Eur. J. Pharmacol. 2008, 585, 163-175.

137. Gustafson, D.R. Adiposity hormones and dementia. J. Neurol. Sci. 2010, 299, 30-34.

138. Gustafson, D.R. Adiposity and cognitive decline: Underlying mechanisms. J. Alzheimers. Dis. 2012, 30, S97-S112.

139. Gustafson, D.R.; Steen, B.; Skoog, I. Body mass index and white matter lesions in elderly women. An 18-year longitudinal study. Int. Psychogeriatr. 2004, 16, 327-336.

140. Profenno, L.A.; Porsteinsson, A.P.; Faraone, S.V. Meta-analysis of alzheimer's disease risk with obesity, diabetes, and related disorders. Biol. Psychiatry 2010, 67, 505-512.

141. Gustafson, D.; Rothenberg, E.; Blennow, K.; Steen, B.; Skoog, I. An 18-year follow-up of overweight and risk of alzheimer disease. Arch. Intern. Med. 2003, 163, 1524-1528.

142. Gustafson, D.R.; Backman, K.; Waern, M.; Ostling, S.; Guo, X.; Zandi, P.; Mielke, M.M.; Bengtsson, C.; Skoog, I. Adiposity indicators and dementia over 32 years in sweden. Neurology 2009, 73, 1559-1566.

(C) 2014 by the authors; licensee MDPI, Basel, Switzerland. This article is an open access article distributed under the terms and conditions of the Creative Commons Attribution license (http://creativecommons.org/licenses/by/4.0/). 